\title{
The Optimal Gasoline Tax for China
}

\author{
C.-Y. Cynthia Lin, Jieyin (Jean) Zeng \\ Department of Agricultural and Resource Economics, University of California at Davis, Davis, USA \\ Email: cclin@primal.ucdavis.edu, zij881128@gmail.com
}

Received 3 February 2014; revised 5 March 2014; accepted 24 March 2014

Copyright $@ 2014$ by authors and Scientific Research Publishing Inc.

This work is licensed under the Creative Commons Attribution International License (CC BY).

http://creativecommons.org/licenses/by/4.0/

(c) (i) Open Access

\begin{abstract}
Gasoline-powered vehicles produce many negative externalities including congestion, air pollution, global climate change, and accidents. A gasoline tax is perhaps the best policy to jointly address these externalities. This paper calculates the optimal gasoline tax for China. Using a model developed by Parry and Small [1] [2], we calculate the optimal adjusted Pigovian tax in China to be $\$ \mathbf{1} .58$ /gallon which is $\mathbf{2 . 6 5}$ times more than the current level. Of the externalities incorporated in this Pigovian tax, the congestion costs are taxed the most heavily, at $\$ 0.82 /$ gallon, followed by local air pollution, accident externalities, and finally global climate change.
\end{abstract}

\section{Keywords}

\section{Gasoline Tax, China}

\section{Introduction}

On January 1, 2009, China initiated a modest reform of its fuel tax, which led to an increase in the gasoline consumption tax from 0.2 Yuan per liter to 1.0 Yuan per liter, and an increase in the kerosene consumption tax from 0.1 Yuan per liter to 0.8 Yuan per liter. Although this reform is considered as a big breakthrough, the changes made are modest since most of the fuel tax simply replaces pre-existing road maintenance fees and some of the tax revenue is given back to fuel consumers who previously did not pay for the road maintenance fees, including airlines, utilities and the army [3]. The existing fuel tax in China is not sufficient to substantially reduce vehicle emissions and congestion, thus raising the issue that what the optimal gasoline tax for China is.

Gasoline-powered vehicles produce many negative externalities including air pollution, global climate change, accidents, and congestion costs. While it has been argued that a gasoline tax is second-best as a corrective measure for each of these externalities separately [2] [4], it is perhaps the best policy to jointly address these externalities due to the cost and difficulty of simultaneously implementing several first-best policies.

The debate over the "optimal" gasoline tax as an incentive policy is ongoing. In this paper, we use a Parry and Small [1] [2] model to calculate the optimal gasoline tax for China. Parry and Small [2], and Lin and Prince [5] 
used this model to calculate the optimal gasoline tax for the US and the UK and for California, respectively.

According to our analysis, the optimal adjusted Pigovian gasoline tax is \$1.58/gallon, which is over 2.65 times over the current level. Of this, the congestion costs are taxed the most heavily, at $\$ 0.82 /$ gallon, followed by local air pollution, accident externalities, and finally global climate change.

In addition to the adjusted Pigovian tax, another possible component of an optimal gasoline tax is the Ramsey tax, which captures the idea that it is more efficient to raise revenue from a tax on gasoline consumption due to the inelasticity of this consumption good. Because of the inelasticity of gasoline consumption and the relatively higher compensated labor elasticity in China, the Ramsey gasoline tax is estimated to $\$ 49.08$, which is around 31 times more than the Pigovian tax part. Due to the large size of the Ramsey component, it is unlikely to be politically implementable.

If we do not account for the Ramsey component, the optimal gasoline tax would be the adjusted Pigovian gasoline tax, which we estimate to be $\$ 1.58$ /gallon, and which is equal to the marginal external cost adjusted down to account for the narrow base of gasoline taxes relative to labor taxes.

The remainder of the paper is organized as follows. Section 2 addresses the primary objectives of raising the gasoline tax for China and arguments for a gasoline tax as a second-best policy. Section 3 lays out the analytical Parry and Small [2] model. Section 4 explains the parameter values chosen for our optimal gasoline tax estimation and presents the results. Section 5 concludes.

\section{Raising the Gasoline Tax in China}

\subsection{Background}

On January 1, 2009, China started a modest reform of its fuel tax, initiated under the nation's top economic planner, the National Development and Reform Commission (NDRC), together with the Ministry of Finance and Ministry of Transport. This was a big breakthrough after 15 years of discussion and debate on fuel tax reform in China.

The new fuel tax policy that was implemented as a result of the reform replaces existing types of fees that were previously levied on road and waterway maintenance and management, raises the fuel consumption tax from 0.2 Yuan per liter to 1.0 Yuan per liter for gasoline, and adds a 0.8 Yuan per liter tax for kerosene. Because gasoline prices fell in 2009, the increase in the gasoline tax initially had a negligible effect on consumers, an effect which gradually increased when the world oil price steadily increased, and which will ultimately cause Chinese consumers to shift their demand for fuel use.

However, compared to European fuel tax reform, most of the fuel tax in China simply replaces the pre-existing road maintenance fees. In addition, some of the tax revenue is given back to fuel consumers who previously did not pay for the road maintenance fees, including airlines, utilities and the army [3]. Therefore, the tax rates are very modest, and in some sense are not sufficient enough to substantially reduce carbon and other vehicle emissions.

\subsection{Components of the Optimal Gasoline Tax for China}

In determining the optimal Pigovian tax on gasoline we have three objectives. The first objective is environmental protection, with particular regard to air pollution and global climate change. According to Mankiw [6], who has proposed a raise in the gasoline tax in the US, higher gasoline taxes are "the most direct and least invasive policy to address environmental concerns". Air pollution and global climate change are both critical environmental issues for China: China tops the list of carbon emissions among the world and its local air pollution is alarming. If greenhouse gases continue to increase, climate models predict that the average temperature at the Earth's surface could increase from $3.2^{\circ} \mathrm{F}$ to $7.2^{\circ} \mathrm{F}$ above 1990 levels by the end of this century [7]. Such climate change could have adverse effects on human health and the environment.

A second objective in determining the optimal Pigovian gasoline tax is the reduction of road congestion and traffic-related accidents. Congestion is a particularly acute problem in China. A Futian survey indicates that the monthly congestion per capita is over 100 Yuan (10\% of disposal income per capita) for five big cities: Beijing, Shanghai, Xi'an, Guangzhou, and Nanjing [8].

A third objective is to reduce dependence on foreign oil. A higher tax on gasoline would discourage oil con- 
sumption, reducing our dependence on fossil fuels, particularly oil imported from OPEC. China imports more than $50 \%$ of the total oil consumption and this number is expected to be even larger in the near future. Leiby [9] defines three components that add to the market price to make up the full cost of petroleum imports. The cost of import demand and its (currently strong) effect on the world oil price and the market power retained by OPEC, the cost of the risk of sudden shortage in the supply of foreign oil, and the cost of active oil security policies. Due to the limited data regarding oil dependence costs in China, we do not include the oil dependence costs when calculating the optimal gasoline tax for China, but note that a higher gasoline tax can reduce our dependence on oil.

Apart from the necessity to account for the negative externalities from gasoline powered passenger vehicles, a tax can also provide government revenue. Several empirical studies have shown that gasoline demand elasticity is relatively inelastic when compared with the demand for leisure. It is important to note here that-if a gasoline tax is the preferred policy-there is still the question of how to deal with the tax revenue. This discussion is beyond the scope of this paper.

\subsubsection{A Gasoline Tax as a Second-Best Policy}

In the economics literature, a Pigovian tax on gasoline is generally considered a second-best policy. For example, Parry and Small [2] note that a tax on emissions would better internalize local air pollution, a tax on peak-period driving would better tackle the congestion problem, and a tax on vehicle miles traveled would most effectively lower accident externalities. These first-best policies can be infeasible, however, because they have a high cost of implementation and monitoring, and no single first-best policy is able to efficiently address all of the objectives discussed above.

\subsubsection{Some Notes on Tax Incidence}

Although most western studies indicate that gasoline tax is likely to be regressive, it may not be the case for developing countries. It has been shown by Cao and Zeng [3] that a gasoline tax in China is likely to be progressive since poor people in China cannot afford to buy cars.

\section{A Model of the Optimal Gasoline Tax}

\subsection{Analytical Framework for Parry and Small Model}

In this section, we lay out the Parry and Small model [2] for an optimal gasoline tax. The style and description in this section closely follows the presentation of Parry and Small [2] and Lin and Prince [5].

The representative agent in a closed economy model has the utility function:

$$
U=u(\Psi(C, M, T, G), N)-\phi(P)-\delta(A)
$$

where the functions $u(\cdot)$ and $\Psi(\cdot)$ are quasi-concave, and $\phi(\cdot)$ and $\delta(\cdot)$ are weakly convex functions representing disutility from pollution and accident risk, respectively. All variables are in per capita terms and defined as follows:

$C$ : quantity of numeraire consumption good;

$M$ : travel measured in vehicle miles;

$T$ : time spent driving; ${ }^{1}$

G: government spending;

$N$ : leisure or non-market time;

$P$ : quantity of (local and global) pollution;

$A$ : severity-adjusted traffic accidents;

$G, P$ and $A$ are all characteristics of an individual's environment and are perceived as exogenous.

Vehicle miles traveled (VMT) are produced according to the homogeneous function:

$$
M=M(F, H)
$$

where $F$ is fuel consumption and $H$ is money expenditure on driving. This function allows for the tradeoff be-

\footnotetext{
${ }^{1}$ Time spent driving is included in the utility function to allow the opportunity cost of travel time to differ from the opportunity cost of work time.
} 
tween vehicle cost and fuel efficiency while holding quality constant. It accounts for the fact that people will buy more fuel-efficient cars in addition to driving less when gasoline prices or taxes increase.

Driving time is a function of VMT, the inverse of the average travel speed $\pi$ and the fixed aggregate miles driven per capita $\bar{M}$ :

$$
T=\pi M=\pi(\bar{M}) M
$$

Because $\bar{M}$ is treated as fixed, $\pi$ will be fixed, implying that drivers do not take into account their own contribution to congestion. We can make the assumption that $\pi^{\prime}>0$, implying that an increase in VMT leads to more congested roads.

Pollution is made up of two types of pollution, $P_{F}$ and $P_{M}$, which differ by the types of externalities they cause. $P_{F}$ is a carbon dioxide type of pollutant, which depends directly on fuel consumption, and therefore causes the fuel-related pollution damages resulting from global climate change: $P_{F}(\bar{F})$, where $\bar{F}$ is aggregate fuel consumption per capita and $P_{F}^{\prime}>0$. In contrast, $P_{M}$ is a pollutant which depends only on miles driven, and therefore causes the distance-related pollution damage resulting from local air pollution ${ }^{2}: P_{M}(\bar{M})$, where $P_{M}^{\prime}>0$. Both costs of pollution from driving are borne by other agents, so those costs are ignored by the agent driving.

The number of accidents per capita is dependent on the amount of aggregate driving per capita and is exogenous to the individual agent:

$$
A=A(\bar{M})=a(\bar{M}) \bar{M},
$$

where $a(\bar{M})$ is the accident rate per mile. Internal costs of accidents such as the risk of an accident impacting an agent's decision about how much to drive, are taken to be implicit and included in either the utility function $\Psi(\cdot)$, or money costs $H$. Other costs are external ${ }^{3}$, and included in $\delta(\cdot)$, where some of these costs are borne by other users of the roads such as pedestrians or cyclists or number of trips. So, disutility from accidents is taken to be independent of the amount of individual's own driving ${ }^{4}$.

On the production side, we assume that firms are competitive and produce all market goods with constant returns to scale. All producer prices and the gross wage rate are exogenously fixed, and normalized to unity, with the exception of gasoline price, $q_{F}$. There is a tax on gasoline, $t_{F}$, and a tax on labor, $t_{L}$.

The agent has a budget constraint:

$$
C+\left(q_{F}+t_{F}\right) F+H=I=\left(1-t_{L}\right) L
$$

where $I$ is disposable income and $L$ is labor supply.

The time constraint on labor, leisure, and driving is given by:

$$
L+N+T=\bar{L}
$$

where $\bar{L}$ is the agent's time endowment.

Government expenditures are financed by taxes. The government does not directly tax or regulate externalities, except as incorporated in the functions $\delta(\cdot), M(\cdot), \pi(\cdot), P_{F}(\cdot), P_{M}(\cdot)$, and $a(\cdot)$. The government has the following budget constraint:

$$
t_{L} L+t_{F} F=G .
$$

With government spending taken as exogenous, this relationship allows a tradeoff between gasoline and labor revenues.

\subsection{Optimal Gasoline Tax Calculation}

The optimal gasoline tax is the one that maximizes utility. If we take the derivative of utility with respect to the gasoline tax and set this equal to zero, after some manipulation (see [1]), the optimal gasoline tax has two maincomponents ${ }^{5}$. The first, an adjusted Pigovian tax, will differ slightly from the marginal external cost of fuel use

\footnotetext{
${ }^{2}$ For example, nitrogen oxides, hydrocarbons, carbon monoxide-regulations force emissions per mile to be uniform across most new vehicles.

${ }^{3}$ Indirect effects on accident externalities via changes in vehicle size are ignored partly because direction of effect is uncertain.

${ }^{4}$ It has been argued that the best policy to address accident externalities is actually a premium on individual driver's vehicle miles traveled through their insurance policy [10] and that a gasoline demand model should include insurance rates.
} 
(MEC). The MEC is comprised of the marginal costs of carbon emissions and dependence on foreign oil-in dollars per VMT - and the marginal costs of distance-related pollution costs, accidents and congestion-in dollars per mile. The latter are multiplied by miles per gallon and the portion of the gasoline demand elasticity due to changes in VMT. The Pigovian tax is the MEC adjusted by a factor of $(1 /(1+\mathrm{MEB}))$, where MEB is the welfare cost in the labor market from an incremental increase in the tax on labor divided by the marginal revenue. This adjustment accounts for the narrow base of gasoline taxes relative to labor taxes, and thus their inferiority in efficiently raising revenues.

The second component is a Ramsey tax. Ramsey [11] proposed the idea that goods with more inelastic consumer demand should be taxed over those with more elastic demand to minimize deadweight loss and maximize government revenue. In this model, Parry and Small [2] base the Ramsey component on the idea that, as vehicle travel becomes a stronger substitute for leisure, the consumer demand for gasoline becomes more inelastic than the compensated demand for leisure.

The formula for the optimal gasoline tax is as follows:

$$
t_{F}^{*}=\text { Adjusted Pigovian tax }+ \text { Ramsey tax },
$$

where:

$$
\begin{gathered}
\text { Adjusted Pigovian tax }=\frac{M E C_{F}}{1+M E B_{L}} \\
\text { Ramsey tax }=\frac{\left(1-\eta_{M I}\right) \varepsilon_{L L}^{c}}{\eta_{F F}} \frac{t_{L}\left(q_{F}+t_{F}\right)}{1-t_{L}}
\end{gathered}
$$

and where:

$$
\begin{aligned}
& M E C_{F} \equiv E^{P_{F}}+E^{O}+\left(\frac{\beta M}{F}\right)\left(E^{C}+E^{A}+E^{P_{M}}\right) \\
& \beta \equiv \frac{\frac{\mathrm{d} M}{\mathrm{~d} t_{F}}}{\frac{\mathrm{d} F}{\mathrm{~d} t_{F}}} \frac{F}{M}=\frac{\eta_{M F}}{\eta_{F F}} \\
& M E B_{L} \equiv \frac{-t_{L} \frac{\partial L}{\partial t_{L}}}{L+t_{L} \frac{\partial L}{\partial t_{L}}}=\frac{\frac{t_{L}}{1-t_{L}} \varepsilon_{L L}}{1-\frac{t_{L}}{1-t_{L}} \varepsilon_{L L}}=\frac{t_{L} \varepsilon_{L L}}{1-t_{L}\left(1+\varepsilon_{L L}\right)}
\end{aligned}
$$

$\eta_{F F}$ is the own price elasticity of demand and $\eta_{M F}$ reflects the portion of this that results from a shift in VMT. $\eta_{M I}$ is the elasticity of demand for VMT with respect to disposable income. $\varepsilon_{L L}^{c}$ and $\varepsilon_{L L}$ are the compensated and uncompensated labor supply elasticity, respectively.

\section{Calculating the Optimal Gasoline Tax}

\subsection{Parameter Values}

We describe below our choices of the parameter values for each of the parameters of our model.

\subsubsection{Initial Fuel Efficiency $M / F: 20.46$ Miles/Gal}

To obtain initial fuel efficiency for China, we use 2009 data from the Transportation Statistical Yearbook to calculate a weighted average of fuel economy for trucks and passenger vehicles respectively. By using vehicle population as the weights, we further average the fuel economy between trucks and passenger vehicles and derive the weighted initial fuel efficiency for all classifications of vehicles. To address the concern of data reliability and the nonlinear nature of fuel economy data, we average the data over several years 2006-2009 and obtain

${ }^{5} \mathrm{~A}$ third component is the congestion feedback, which Parry and Small [2] and Lin and Prince [5] find to be negligible. 
a range for initial fuel efficiency, which is 20.46 miles per gallon.

\subsubsection{Local Air Pollution Damages (Distance Related) $E^{P_{M}}: 2.34$ Cents/Mile}

Due to lack of related studies in air pollution damages, we refer to the US data from Parry and Small [2]. The estimate of health damage from local air pollution is based on the estimate of the value of a statistical life, which can be different in each country. However, several studies took the values of life from the European value or US value. It should be noted here there is uncertainty in estimating this value and therefore to make the results robust, we will give a range of local air pollution damages in our gasoline tax calculation.

\subsubsection{Global Climate Change Pollution Damages (Fuel Related) $E^{P_{F}}: 7.03$ Cents/Gallon}

Again, we take this value from Parry and Small's [2] estimates of 2.9 cents per mile and 6 cents per gallon respectively, updated to 2006 prices. They represent the damages from local air pollution and global climate change, respectively. It should be noted here that these values are very rough estimates and Parry and Small [2] make a point to emphasize the "great uncertainty" here. Further, the values that Parry and Small [2] report are for the United States. Regardless, it is important to notice that the fuel related pollution damages are small in comparison to local pollution.

\subsubsection{External Congestion Cost $E^{C}: 2$ Cents/Mile - 4.4 Cents/Mile}

We take this value from a 2008-2009 survey conducted by Futian Company for 9 big cities including Beijing, Shanghai, Chongqing, Xi'an, Guangzhou, Ha'erbin, Wuhan, Nanjing and Chengdu. According to our personal experiences, China is experiencing congested traffic in those big cities where as there is not as much traffic in those small towns. Therefore, it is quite uncertain how to average it over the whole big country. To solve this problem, we decide to plug in the congestion costs for each big city separately and estimate their respective optimal gasoline tax. One noticeable result is that the congestion costs contribute a large part to the estimate of optimal gasoline tax. Since we are still interested in the optimal gasoline tax for the whole country, we take a range of congestion costs for the whole country, from 2 cents/mile to 4.4 cents/mile.

\subsubsection{External Accident Cost $E^{A}: 1.415$ Cents/Mile}

We get the direct economic costs of accidents in 2009 at regional level from statistical year book. From an economic perspective, the direct economic costs are just a small part of the external accident costs, as the external accident costs should be the product of the value of life and the risk exposed to accidents. Again, due to data limitation, we refer to the US value, 2.83 cents/mile as our upper bound for external accident costs. We use as our range 0.000023 cents/mile to 2.83 cents/mile.

\subsubsection{Gasoline Price Elasticity $\eta_{F F}:-0.23$}

We use the value of the price elasticity of gasoline demand in China estimated by Lin and Zeng [12]. In particular, we use their point estimate for the intermediate-run price elasticity of gasoline demand from their instrumental variables regression using diesel price as an instrument for gasoline price.

\subsubsection{Elasticity of VMT with Respect to Consumer Fuel Price $\eta_{M F}:-0.633$}

We base our value of the price elasticity of VMT in China on those estimated by Lin and Zeng [12].

\subsubsection{VMT Portion of Gasoline Price Electricity $\beta \equiv \frac{\eta_{M F}}{\eta_{F F}}: 2.74$}

Based on dividing the elasticity of VMT by the elasticity of demand for gasoline with respect to consumer fuel price, we estimate the VMT portion $\beta$ of the gasoline price elasticity for China to be 2.74. $\beta$ represents the portion of gasoline elasticity demand that is due to a change in vehicle miles traveled versus, for instance, increases in fuel economy.

\subsubsection{VMT Expenditure Elasticity $\eta_{M I}:-0.044$}

This component captures the elasticity of VMT demand with respect to disposable income. Regressions using China data and a static model for intermediate-run analysis yield an insignificant estimate of -0.044 . Lin and 
Prince [5] estimated the short-run VMT expenditure elasticity to be 0.065 for California. Parry and Small [2] set the central value for expenditure elasticities at 0.6 and 0.8 for US and UK, relatively. From this, we can conclude that the expenditure elasticity of VMT expenditure elasticity is small. And it can be negative or positive because with the rise of residential income, there exists opposing effects of increased vehicle ownership and the trends of urbanization which means people do not have to travel so much as they did in the past. Therefore, we set the central value for VMT expenditure elasticity at -0.044 with a range from -0.1 to 0.1 .

\subsubsection{Uncompensated Labor Supply Elasticity $\varepsilon_{L L}: 0.017$}

We used the uncompensated labor supply elasticity from Li and Zax [13].

\subsubsection{Compensated Labor Supply Elasticity $\varepsilon_{L L}^{c}: 0.997$}

We used the compensated labor supply elasticity from Li and Zax [13].

\subsubsection{Producer Price of Gasoline $q_{F}: 280$ Cents/Gallon}

Producer price of gasoline is an average of retail gasoline prices from January 2009 to December 2009.

\subsubsection{Government Spending G: 843.9 Billion Dollars}

From the 2011 Statistical Yearbook of China, Chinese government consumption in 2010 is 5361.4 billion Yuan. After converting into dollars, we get 843.9 billion dollars.

\subsubsection{Labor Income $L: 2639.8$ Billion Dollars}

The income per capita for urban and rural areas is 19,109 and 5919 Yuan relatively, with respective population of 669.78 and 67.113 million in 2010. After summing them up and converting into dollars, we get the labor income of 2639.8 billion dollars.

\subsubsection{Taxable Gasoline Sales $S(g): 22.042$ Billion Gallons}

From the 2010 Energy Statistical Yearbook, the total gasoline consumption in 2010 is 61.7 million tonnes. We converted this value to gallons by utilizing an average gasoline weight density of $6.175 \mathrm{lb} / \mathrm{US}$ gallon.

\subsubsection{Initial Tax Rate on Gasoline $t_{f}^{0}: 59.60$ Cents/Gallon}

The current tax on gasoline in China is 1 Yuan/liter, that is 59.60 cents/gallon. This is the excise tax for gasoline which is initiated in January of 2009.

\subsection{Optimal Gasoline Tax}

Table 1 presents our results for the calculation of the optimal gasoline tax for China under our base-case parameter values as well as for a range of values for each parameter, holding the values of all other parameters at their base-case values. Table 2 presents the components of the base-case adjusted Pigovian tax. Table 3 presents the adjusted Pigovian tax and the Ramsey tax for two major cities in China: Beijing and Shanghai.

\section{Concluding Remarks}

Although China has initiated a reform of its fuel tax which is considered as a big breakthrough, the existing fuel tax is still low when compared with other western countries. The fuel tax reform is modest because most of the fuel tax simply replaces pre-existing road maintenance fees and some of the tax revenue is given back to fuel consumers who previously did not pay for the road maintenance fees, including airlines, utilities and the army [3]. In this paper we calculate the optimal gasoline tax for China to be $\$ 1.58 /$ gallon, with the congestion costs taxed the most heavily, at $\$ 0.82$ /gallon, followed by local air pollution, accident externalities, and finally global climate change.

However, there is a considerable political barrier when it comes to the issue of raising the gasoline tax, as it took 15 years for China to initiate its modest tax reform. It has been shown that the gasoline tax in China is likely to be progressive since the poor are not able to afford a car. Free of the equity concern, perhaps the most important consideration should be that of the inelastic demand for gasoline in China. With highly inelastic gasoline demand, any incentive policy would have to induce a large shock to prices to induce a behavioral change. We 
Table 1. Estimation results for optimal gasoline tax.

\begin{tabular}{|c|c|c|c|c|c|c|c|}
\hline & \multicolumn{3}{|c|}{ Parameter Values } & \multicolumn{2}{|c|}{$\begin{array}{l}\text { Adjusted Pigovian Tax } \\
\text { Using Low and High } \\
\text { Range Values } \\
\text { (cents/gallon) }\end{array}$} & \multicolumn{2}{|c|}{$\begin{array}{l}\text { Ramsey Tax } \\
\text { Using Low and High } \\
\text { Range Values } \\
\text { (cents/gallon) }\end{array}$} \\
\hline & Base Case & Low & High & Low & High & Low & High \\
\hline Initial fuel efficiency & 20.46 & 18.4 & 22.4 & 142.8 & 172.1 & 4910.3 & 4907.2 \\
\hline Pollution damages, local air pollution (cents/mile) & 2.34 & 0.47 & 11.7 & 123.6 & 327.5 & 4912.1 & 4887.1 \\
\hline $\begin{array}{l}\text { Pollution damages, global climate } \\
\text { change (cents/gallon) }\end{array}$ & 7.03 & 0.23 & 28.1 & 151.2 & 178.7 & 4909.3 & 4906.2 \\
\hline External congestion cost (cents/mile) & 4.4 & 1.4 & 7.4 & 102.7 & 212.8 & 4913.1 & 4903.6 \\
\hline External accident cost (cents/mile) & 1.415 & 0.00002 & 2.83 & 131.9 & 183.8 & 4911.3 & 4905.7 \\
\hline Gasoline price elasticity & -0.23 & -0.17 & -0.4 & 164.3 & 168.2 & 6129.8 & 2338.3 \\
\hline $\begin{array}{l}\text { Elasticity of VMT with respect to } \\
\text { consumer fuel price }\end{array}$ & -0.633 & -0.3 & -1 & 185.8 & 94.41 & 4905.7 & 4914.2 \\
\hline VMT expenditure elasticity & -0.044 & -0.1 & 0.1 & 155.4 & 166.1 & 5134.9 & 4239.2 \\
\hline Uncompensated labor supply elasticity & 0.017 & 0 & 0.2 & 158.4 & 152.0 & 4908.6 & 4908.8 \\
\hline Compensated labor supply elasticity & 0.997 & 0.5 & 1.2 & 217.7 & 150.0 & 1834.4 & 5686.0 \\
\hline Producer price of gasoline (cents/gallon) & 280 & 200 & 300 & 161.45 & 157.3 & 3501.2 & 5260.4 \\
\hline Adjusted Pigovian tax (cents/gallon) & 157.9 & 45.2 & 326.6 & & & & \\
\hline Ramsey tax (cents/gallon) & 4908.5 & 2367.7 & 3087.9 & & & & \\
\hline
\end{tabular}

Notes: The adjusted Pigovian tax using low and high range values and the Ramsey tax using low and high range values were calculated using low and high ranges for each respective parameter while holding all other parameter values at their base-case values.

Table 2. Components of optimal gasoline tax.

\begin{tabular}{ll}
\hline Components of optimal gasoline tax & Cents/gallon \\
\hline Adjusted Pigovian tax: & 157.90 \\
Global climate change & 7.03 \\
Local air pollution & 43.44 \\
Congestion & 81.69 \\
Accidents & 26.27 \\
Ramsey tax & 4908.47 \\
\hline
\end{tabular}

Table 3. Pigovian tax and Ramsey tax for cities (cents/gallon).

\begin{tabular}{ccc}
\hline Components of optimal gasoline tax rate & Beijing & Shanghai \\
\hline Adjusted Pigovian tax: & 937.28 & 916.77 \\
Global climate change & 7.03 & 7.03 \\
Local air pollution & 65.39 & 63.96 \\
Congestion & 743.33 & 727.07 \\
Accidents & 122.96 & 120.27 \\
Ramsey tax & 782.26 & 919.19 \\
\hline
\end{tabular}


focus on what Lin and Zeng [12] estimate to be an intermediate-run elasticity; however, we calculate the optimal gasoline tax over a broad range of elasticities so that policy makers with time varying objectives can better understand how a gasoline tax might change consumer behavior. For example, if the objective is to curb gasoline consumption in the very short run, a gasoline tax should be quite high. On the other hand, if the objective is to incentivize changes over a longer period of time, a lower tax would be appropriate. Based on our analysis, it is likely that—even in the long run—any tax on gasoline meant to address the objectives discussed above for the state of China should be higher than that which is currently in place.

\section{Financial Support}

We thank the UC-Davis ITS Sustainable Transportation Energy Pathways program for financial support.

\section{References}

[1] Parry, I. and Small, K. (2004) Does Britain or the United States Have the Right Gasoline Tax? Resources for the Future Discussion Paper, 02-12 rev.

[2] Parry, I. and Small, K. (2005) Does Britain or the United States Have the Right Gasoline Tax? American Economic Review, 95, 1276-1289. http://dx.doi.org/10.1257/0002828054825510

[3] Cao, J. and Zeng, J. (2010) The Incidence of Carbon Tax in China. Working Paper Presented at Lincoln Institute China Program Annual May Conference, Cambridge, 17 May 2010.

[4] Fullerton, D. and West, S. (2003) Public Finance Solutions to Vehicle Emissions Problems in California. The Berkeley Electronic Press, Berkeley. http://www.bepress.com/fullertonwest

[5] Lin, C.-Y.C. and Prince, L. (2009) The Optimal Gas Tax for California. Energy Policy, 37, 5173-5183. http://dx.doi.org/10.1016/j.enpol.2009.07.063

[6] Mankiw, G. (2006) The Pigou Club Manifesto. http://Gregmankiw.blogspot.com/2006/10/pigou-club-manifesto.htm

[7] Environmental Protection Agency [EPA] (2009) Climate Change. http://www.epa.gov/climatechange/basicinfo.html

[8] Lingdian Consulting Firm (2009) Futian Index. http://auto.sina.com.cn/csgc/q0904/index.shtml

[9] Leiby, P. (2007) Estimating the Energy Security Benefits of Reduced US Oil Imports. Oak Ridge National Laboratory, ORNL/TM-2007/028.

[10] Edlin, A.S. and Mandic, P.K. (2006) The Accident Externality from Driving. Journal of Political Economy, 114, 931955. http://dx.doi.org/10.1086/508030

[11] Ramsey, F.P. (1927) A Contribution to the Theory of Taxation. Economic Journal, 37, 47-61. http://dx.doi.org/10.2307/2222721

[12] Lin, C.-Y.C. and Zeng, J. (2013) The Elasticity of Demand for Gasoline in China. Energy Policy, 59, 189-197. http://dx.doi.org/10.1016/j.enpol.2013.03.020

[13] Li, H. and Zax, J.-S.J. (2003) Labor Supply in Urban China. Journal of Comparative Economics, 31, 795-817. http://dx.doi.org/10.1016/j.jce.2003.08.003 